\title{
DYNAMIC MORPHOLOGICAL CHANGES OF SPIT IN APRIL-MAY 2014 IN OPAK RIVER MOUTH, BANTUL, DAERAH ISTIMEWA YOGYAKARTA
}

\author{
Yan Restu Freski, Agung Setianto, and Srijono \\ Geological Engineering Department, Faculty of Engineering, Universitas Gadjah Mada
}

\begin{abstract}
As an oceanic coast, the beaches in the southern part of Java Island are predominantly influenced by ocean energy which is driven by periodical monsoon. This periodical process impacts the dynamic changes of spit in the river mouth system. Therefore, spit is a key to study the process in the southern coast of Java Island especially in Opak River Mouth. It needs a deep-root explanation about the morphological changes and the sedimentological mechanism. This research project was built by data such as spit geometry, aerial photographs and spontaneous wind direction. The supporting data included multitemporal IKONOS-Quickbird images from Google Earth and aerial photographs. These data were collected from field-work investigation and laboratorywork. The spit geometry was compiled by Global Positioning System handheld tracking along the edge of spit and crosschecked by aerial photograph using pole. The ultimate interpretation and periodic models were built by data reconstruction based on the geometry of spit and spontaneous wind direction. Spit changed weekly due to monsoon transition in April to May 2014. The morphological changes could be noted as the spit starting to be cut off by the highrate flow of Opak River. The process continued until the net drift moving westward.
\end{abstract}

Keywords: April, coast, May, Opak river mouth, spit.

\footnotetext{
${ }^{*}$ Corresponding author: A. SETIANTO, Geological Engineering Department, Faculty of Engineering, Universitas Gadjah Mada. Jl. Grafika No. 2 Yogyakarta 55281, Indonesia. E-mail: agung_setianto@ugm.ac.id
}

\section{Introduction}

Coastal area reflects to the results of oceanic and fluvial energies (Komar, 1976). The coastline of Java Island in Indonesia is approximately $3000 \mathrm{~km}$ long (Zazoeli and Negoro, 1989). The southern part of the coast which faces directly to Indo-Australia Ocean, has some distinct features due to the oceanic waves and current. The oceanic processes depend on the periodical monsoon throughout years (Tjasyono, 2004). The influence can be seen on the spit, the river mouth bar along the beach (Komar, 1976).

Spit is the sediment along the beach in front of the river mouth. It is formed because the wave crest angled with coastline (Wright and Coleman, 1973 in Leeder, 1999). It also becomes the barrier of river near the inlet of river mouth (Steers, 1953, in Komar, 1976). During April May 2014, the wind which is presumed as the main factor of coastal processes is the transitional monsoon. The wind blows from eastward in the southern coastal of Java. It presents the monsoonal changes from wet season to dry season. This time become important periode since the significant changes of processes happened within. By this critical time, the study of the dynamic morphological changes of spit and the inlet are necessary. The research has been conducted in the river mouth area of Opak River which is located in the southern coast of Java, Bantul Regency, Daerah Istimewa Yogyakarta. The exact location was at $49 S 420990$ 


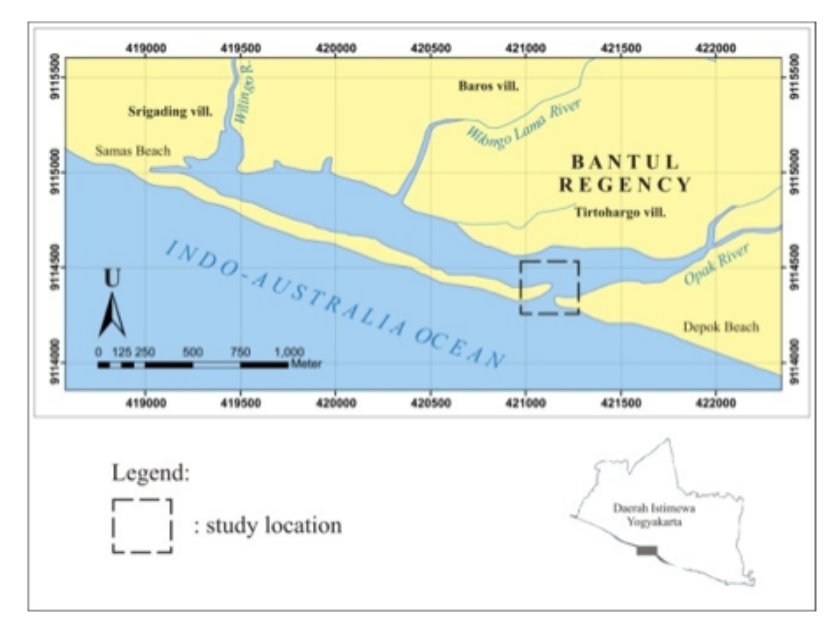

Figure 1: The study area in Opak River mouth, Bantul, Daerah Istimewa Yogyakarta.

- 421280 and $9114250-9114525$. The situation of the area can be seen at Figure 1 .

The questions of this research is how was the dynamic changes of morphology of the spit during transitional monsoon (April - May 2014)? The research focused on the inlet of the Opak river mouth which had a clear movement of the spit. The time of this investigation was April to May 2014 which was presumed as transition monsoon from west to east.

\section{Materials and methods}

This research project was built by data such as spit geometry and aerial photographs scaled 1:30. The supporting data included multitemporal IKONOS and or Quickbird images from Google Earth (March 7, 2010; May 24, 2012; and August 2, 2013) and aerial photographs scaled 1:25.000. These data were collected from field-work investigation and laboratory-work. The spit geometry was compiled by Global Positioning System handheld tracking along the edge of spit and crosschecked by aerial photograph using pole. The measurement of wind was carried on by using the flag indicator and compass. The ultimate interpretation and periodic models were built by data reconstruction based on the geometry of spit and spontaneous wind direction.

The main obstacle of data collecting was the validity of the wind data since the measure- ment using the compass. The area of study is rich by ferromagnetic minerals (magnetite, ilmenite, etc.) and it might affect the compass needle. By this condition, the wind direction data was crosschecked by Badan Informasi Geospasial (BIG) data. This was also completed by the time when it was gathered and mentioned as the spontaneous direction. This wind data gives small representatives that compared to the global wind.

\section{Results and discussion}

Opak Spit can be defined as a part of an estuary system. Based on Fairbridge (1980, in Huggett, 2007), the estuary and the spit of Opak can be classified as bar-built estuary while in Wright (1985, in Huggett, 2007), they can be associated with wave dominated delta since there are similar features of it. Spit is commonly developed as progradation along the coastline which segmented by river inlet within the spit (Reinson, 1992). Sandy (1979, in Verstappen, 2000) and Setyawan (2002) also mentioned in geological time, the southern coast of Central Java has been prograding to the sea.

Figure 2 shows the morphological changes through the time from Desember 22, 2000, March 7, 2010, May 24, 2010, and August 2, 2013. The changes give an opportunity to be observed and calculated. At least it can be explained with many factors such as beach process, latitude and monsoon, lithological setting and the regional physiography surrounding (Soetoto and Widiasmoro, 1987; Subardi, 1994; Triatmodjo, 1999; Hendratno, 2000; Verstappen, 2000; Surjono, 2001; Setyawan, 2002; Tim Morfodinamika Pesisir, 2009; Freski and Darmadi, 2012; Srijono and Freski, 2013).

The correlation between date, monsoon, and global sea currents based on Figure 2, can be seen in Table 1. Based on Wiratmo (2013), Tjasyono (2004), and Birowo and Uktolseya (1982, in Setyawan, 2002), in August, there is eastern monsoon which drives South Equatorial Current to west. Eastern monsoon triggered the dry season in Indonesia. By this condition, the water supply from the rain in the land decreased. 

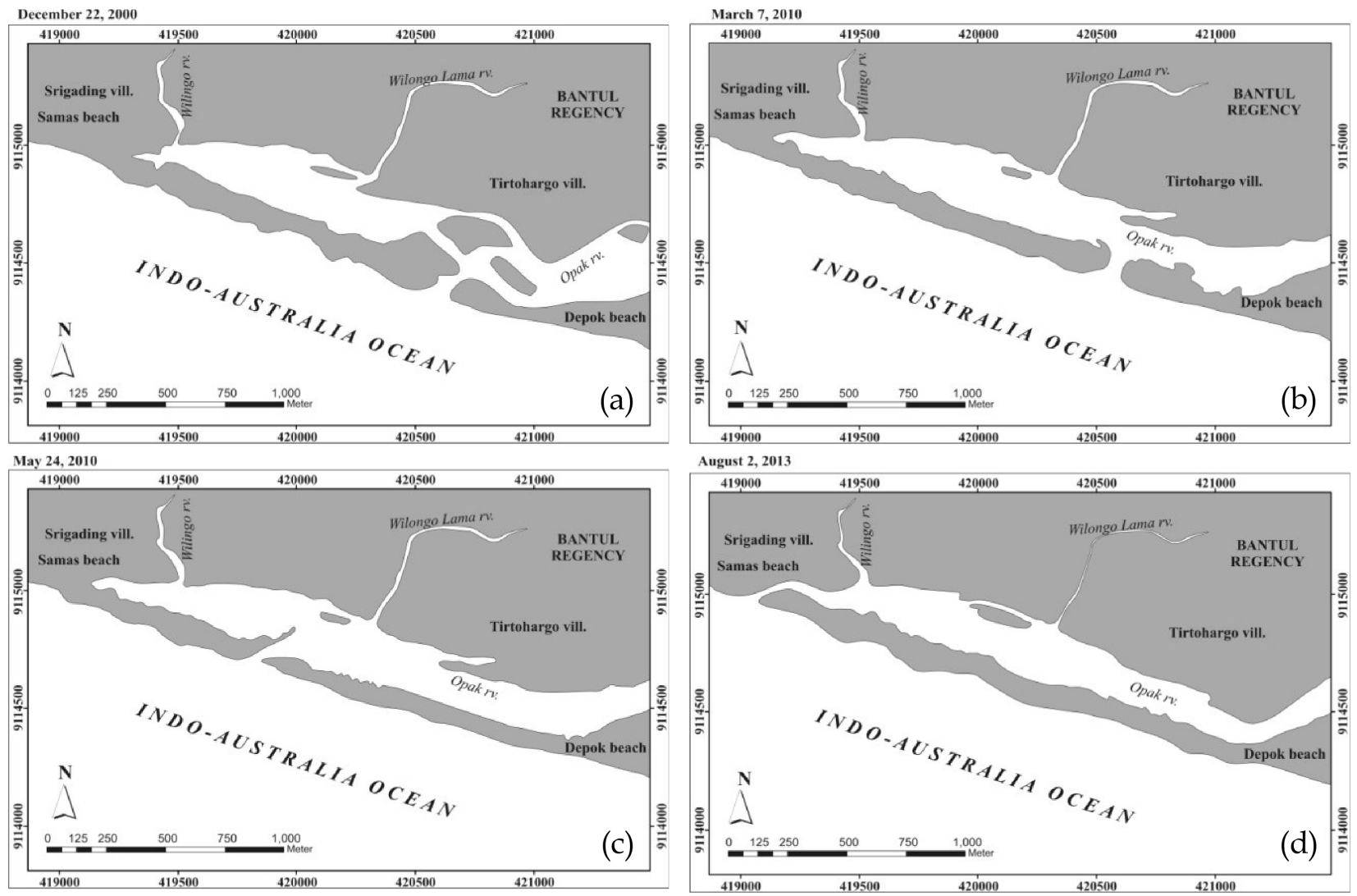

Figure 2: The morphological changes of the Opak river mouth and its spit on (a) Desember 22, 2000, (b) March 7, 2010, (c) May 24, 2010, and (d) August 2, 2013 (as results of images and aerial photographs analysis). 
Table 1: The correlation between date, monsoon, and global sea currents that applied in Opak river mouth.

\begin{tabular}{|c|c|c|}
\hline Date & $\begin{array}{c}\text { Monsoon } \\
\text { (Wiratmo, } \\
\text { 2013) }\end{array}$ & $\begin{array}{c}\text { Current type } \\
\text { (Birowo and } \\
\text { Uktolseya, 1982 } \\
\text { in Setyawan } \\
\text { 2002) }\end{array}$ \\
\hline $\begin{array}{c}\text { Aug 22, } \\
2000\end{array}$ & $\begin{array}{c}\text { Eastern } \\
\text { monsoon }\end{array}$ & $\begin{array}{c}\text { South Equatorial } \\
\text { Current }\end{array}$ \\
\hline $\begin{array}{c}\text { Mar 7, } \\
2010 \\
\text { May 24, } \\
2010 \\
\text { from east to } \\
\text { west }\end{array}$ & $\begin{array}{c}\text { Transition } \\
\text { monsoon } \\
\text { from east to } \\
\text { west }\end{array}$ & $\begin{array}{c}\text { Java Coastal } \\
\text { Current }\end{array}$ \\
\hline $\begin{array}{c}\text { Aug 2, } \\
2013\end{array}$ & $\begin{array}{c}\text { Eastern } \\
\text { monsoon }\end{array}$ & $\begin{array}{c}\text { South Equat } \\
\text { Current }\end{array}$ \\
\hline
\end{tabular}

There was no plenty run off so the rate of water flow declined even in the river mouth. The river energy dropped out and became lower than the sea which was precisely increased from eastsoutheast.

The condition differed on March 7, 2010 which was the end of western monsoon. The inlet formation cut the spit at the eastern arm. It was supported by the high rate of river flow due to the wet season. Simultaneously, the spit elongated to east because of Java Coastal Current as well as on May 24, 2010. The inlet drifted westward on March 7, 2010. The coastal process then was mostly controlled by the sea current. It continued until August which influenced by South Equatorial Current (Birowo dan Uktolseya, 1982, in Setyawan, 2002).

Thus, the interpretation of spit morphology closely related to the periodical monsoon. It can be used to explain the coastal processes during April to May 2014. The geometrical changes of the spit can be seen at Table 2. All sequences represented the effect of transitional monsoon (from west to east) and the Java Coastal Current with the inlet position took a place in the east part of spit. (Birowo dan Uktolseya, 1982, in Setyawan, 2002). The sequences can be seen in 3-dimensional model at Figure 3

In studying the double spits, a comprehensive observation must be applied. The spit would extend along the drift direction (Swan, 1983 in Setyawan, 2002). In the study area, the spit condition in October 2013 still covered by the washover deposits with approximately $150 \times 100$ meter along to the estuary. The overweigh washover might caused the vertical erosion of the spit. It led new inlet formation as in November 2013, a month later (Srijono dan Freski, 2013). The new inlet had the rate of flow approximately $0.1-1.0 \mathrm{~m} / \mathrm{s}$.

The shape changing of the spit was obviously observed by geometry aspect. In April - May 2014, its geometry became wider and showed the drifting to west. Its changes appropriate with the transitional trend of wind direction from eastward to westward (Wiratmo, 2013). The effective drifting of the spit also showed the concepts from Birowo and Uktolseya (1982, in Setyawan, 2002). Srijono and Freski (2013) concluded that November 2013 as the time of the spit cutting can be justified as the last datum of spit growth eastward. It means, the interval time between April to May 2014 can be presumed as the early datum of spit growth westward.

\section{Conclusions}

Dynamic changes of spit morphology of Opak river mouth in transition monsoon from west to east (April - May 2014) was significantly seen. The southwest-western wind in April dominated the beach process. It generated the southwest-western nearshore current which takes a role in the spit movement. Gradually, the wind direction shifted to southsoutheastern wind and then controlled the spit process. At the beginning of the transition period (April), the west spit has been more affected than the east and vice versa in May. 
Table 2: The Geometrical changes of the spit in April - May 2014.

\begin{tabular}{|c|c|c|c|}
\hline $\begin{array}{l}\text { Week, date, } \\
\text { Spontaneous } \\
\text { wind direction } \\
\text { and sea level } \\
(\mathrm{BIG}, 2014)\end{array}$ & $\begin{array}{l}\text { Geometry of the spit in the } \\
\text { inlet of Opak river mouth }\end{array}$ & $\begin{array}{l}\text { Week, date, } \\
\text { Spontaneous } \\
\text { wind direction } \\
\text { and sea level } \\
(\mathrm{BIG}, 2014)\end{array}$ & $\begin{array}{l}\text { Geometry of the spit in the } \\
\text { inlet of Opak river mouth }\end{array}$ \\
\hline $\begin{array}{c}\text { Week I, } \\
\text { April 5, 2014, } \\
\text { (not measured) } \\
0.45 \mathrm{~m} \\
\text { Time 11:00- } \\
\text { 12:00 WIB }\end{array}$ & $\prod_{\text {OPAK RIVER }}^{\text {R212000 }}$ & $\begin{array}{c}\text { Week V, } \\
\text { May } 4 \text { \& 6, } 2014 \\
\text { South- } \\
\text { Southwest } \\
\left(\mathrm{N} 179^{\circ} \mathrm{E}-\right. \\
\left.\mathrm{N} 228^{\circ} \mathrm{E}\right) \\
0.5 \mathrm{~m} \\
\text { Time 11:00- } \\
\text { 12:00 WIB }\end{array}$ & 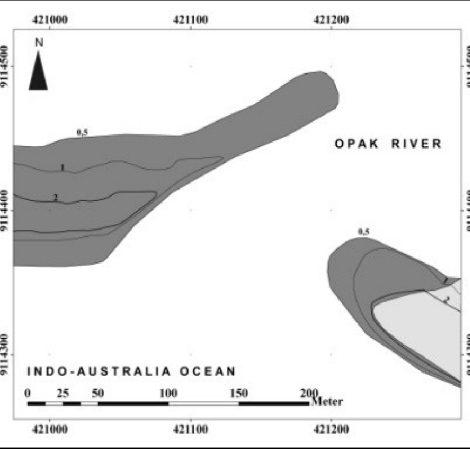 \\
\hline $\begin{array}{c}\text { Week II, } \\
\text { April 12, 2014, } \\
\text { Southwest-West } \\
\left(\mathrm{N} 230^{\circ} \mathrm{E}-\right. \\
\left.\mathrm{N} 260^{\circ} \mathrm{E}\right) \\
0.7 \mathrm{~m} \\
\text { Time 15:00- } \\
\text { 17:00 WIB }\end{array}$ & 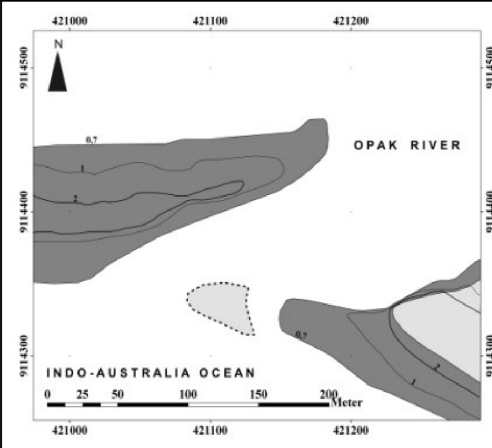 & $\begin{array}{c}\text { Week VI, } \\
\text { May 13, 2014, } \\
\text { South- } \\
\text { Southeast } \\
\left(\mathrm{N} 139^{\circ} \mathrm{E}-\right. \\
\left.\mathrm{N} 176^{\circ} \mathrm{E}\right) \\
0.7 \mathrm{~m} \\
\text { Time 15:00- } \\
\text { 17:00 WIB }\end{array}$ & 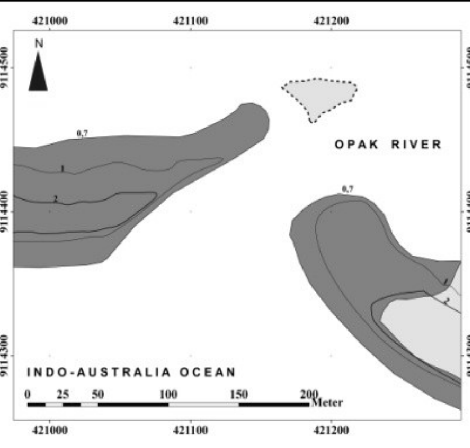 \\
\hline $\begin{array}{l}\text { Week III, } \\
\text { April 20, 2014, } \\
\text { Southwest } \\
\left(\mathrm{N} 220^{\circ} \mathrm{E}-\right. \\
\left.\mathrm{N} 245^{\circ} \mathrm{E}\right) \\
0.25 \mathrm{~m} \\
\text { Time 11:00- } \\
\text { 12:00 WIB }\end{array}$ & 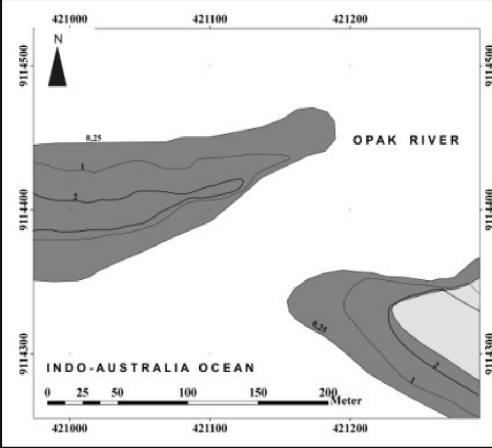 & $\begin{array}{l}\text { Week VII, } \\
\text { May 20, 2014 } \\
\text { Southeast } \\
\left(\mathrm{N} 141^{\circ} \mathrm{E}-\right. \\
\left.\mathrm{N} 169^{\circ} \mathrm{E}\right) \\
0.40 \mathrm{~m} \\
\text { Time 11:00- } \\
\text { 12:00 WIB }\end{array}$ & 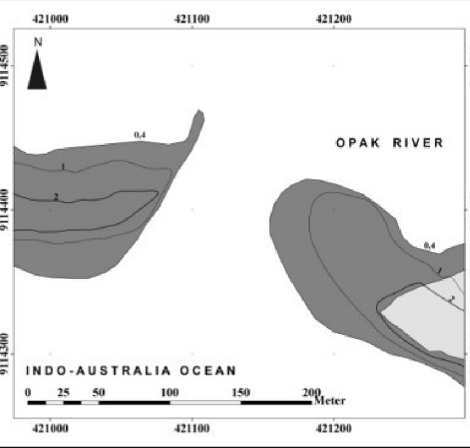 \\
\hline $\begin{array}{c}\text { Week IV, } \\
\text { April 26, 2014, } \\
\text { Southwest-West } \\
\left(\mathrm{N} 219^{\circ} \mathrm{E}-\right. \\
\left.\mathrm{N} 295^{\circ} \mathrm{E}\right) \\
0.65 \mathrm{~m} \\
\text { Time 15:00- } \\
\text { 17:00 WIB }\end{array}$ & 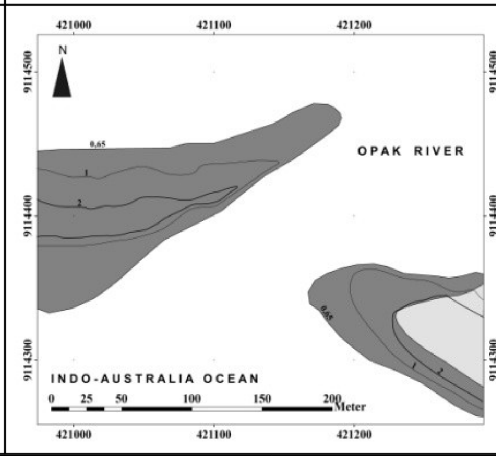 & $\begin{array}{l}\text { Week VIII, } \\
\text { May 27, 2014 } \\
\text { Southeast } \\
\left(\mathrm{N} 130^{\circ} \mathrm{E}-\right. \\
\left.\mathrm{N} 140^{\circ} \mathrm{E}\right) \\
0.7 \mathrm{~m} \\
\text { Time 15:00- } \\
\text { 17:00 WIB }\end{array}$ & 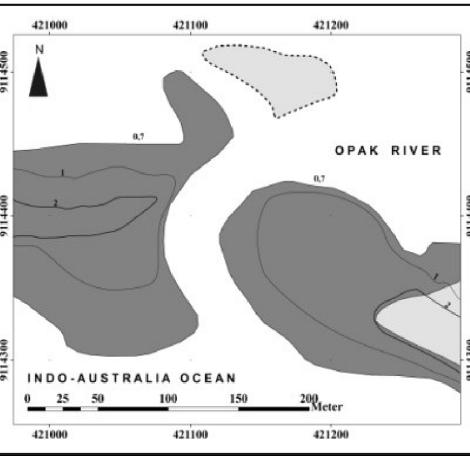 \\
\hline \multicolumn{4}{|r|}{$\begin{array}{l}\text { sometimes } \\
\text { appears as } \\
\text { land }\end{array}$} \\
\hline
\end{tabular}



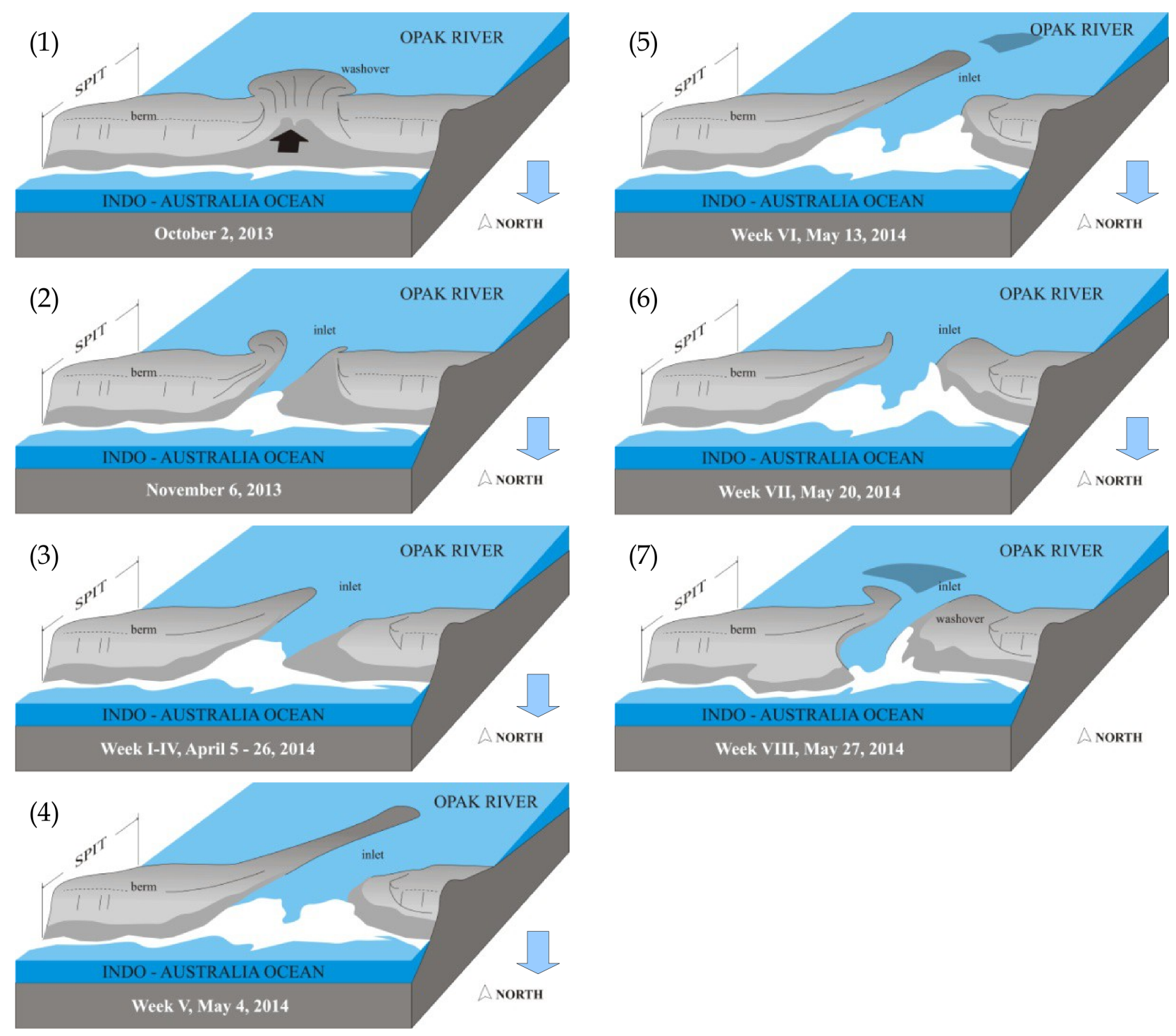

Figure 3: The sequence of the spit changes from the inlet formation to the westward netdrift of the spit during the transitional monsoon: (1) a constant washover which occurred in the same line of the spit caused lower elevation of spit due to its vertical erosion, (2) the river energy elevated because of the increasing of the flow rate, (3) the process of stagnancy was carried on due to the direction drifting of the sea current, in other word, the wave travel direction was perpendicular to the shoreline, (4) the netdrift of spit to the west can be seen by the addition of the sediment in the eastern spit, (5) the erosion process began on the western spit, (6) the elongated geometry of the western spit stopped and the erosion continued, (7) the erosion took a part on the drifting of the spit until the eastern spit grew westward. 


\section{Acknowledgment}

A grateful expression is addressed to Laboratory of Dynamic Geology and Laboratory of Sedimentology of Geological Engineering Department, University of Gadjah Mada who has supported the research.

\section{References}

Anonim (2014) Images IKONOS-Quickbird dated March 7, 2010, May 24 2012, and August 2, 2013 accessed from Google Earth, August 19, 2014.

Freski, Y.R. and Darmadi (2012) Analisis pembelokan aliran Sungai Opak saat bermuara di Samudra Hindia. Dalam Prosiding PIT IAGI ke-41, Yogyakarta.

Hendratno, A. (2000) Kondisi Geologi Untuk Pengembangan Lingkungan Fisik Wilayah Pesisir Selatan Yogyakarta Antara Muara Sungai Opak dan Girijati. Master Thesis in Postgraduate School of Universitas Gadjah Mada, Yogyakarta.

Huggett, R.J. (2007) Fundamentals of Geomorphology 2nd Edition. Routledge, New York, 483h.

Komar, P.D. (1976) Beach Processes and Sedimentation. Prentice Hall, New Jersey, 429p.

Leeder, M. (1999) Sedimentology and Sedimentary Basins from Turbulence to Tectonics. Blackwell Publishing, United States, 581p.

Reinson, G.E. (1992) Transgressive Barrier Island and Estuarine Systems. Dalam: Walker, R.G. dan James, N.P. Facies Models Response to Sea Level Changes. Geological Association of Canada Publications, Canada.

Setyawan, W.B. (2002) Bentang alam pantai di pesisir selatan Jawa Tengah. Sumber Daya Geologi Daerah Istimewa Yogyakarta dan Jawa Tengah. Pengurus Daerah Ikatan Ahli Geologi DIY \& Jawa Tengah.
Soetoto dan Widiasmoro (1987) Concepts of coastal region development in Southern Yogyakarta Province based on geological data through Landsat imagery and aerialphotographs interpretations. Proceeding of Ann. Reg. Meet. IAGI, Jakarta.

Subardi (1994) Geologi Pantai Parangtritis, Yogyakarta. Proceeding of Ann. Meet. IAGI XXIII, Jakarta.

Surjono, S. S. (2001) Geodinamika Muara Sungai Serang dan Bogowonto Kabupaten Kulon Progo Daerah Istimewa Yogyakarta Sebagai Pertimbangan Rencana Pengembangan Wilayah. Master Thesis in Postgraduate School of Universitas Gadjah Mada, Yogyakarta.

Srijono and Freski, Y.R. (2013) Mekanisme pembentukan spit pada muara Sungai Opak dalam morfodinamika pesisir selatan $\mathrm{Pu}$ lau Jawa berdasarkan analisis citra multitemporal. Proceeding of National Seminar, Geological Engineering Department, FoE UGM, Yogyakarta.

Tim Morfodinamika Pesisir (2009) Studi Morfodinamika Wilayah Pesisir Selatan Kabupaten Bantul dan Kabupaten Cilacap. Internal Report of Laboratory of Geospatial, Yogyakarta.

Tjasyono, B. (2004) Klimatologi. ITB Publisher, Bandung.

Triatmodjo, B. (1999) Teknik Pantai. Beta Offset, Yogyakarta, 396p.

Verstappen, H.T. (2000) Outline of the Geomorphology of Indonesia: A Case Study On Tropical Geomorphology of A Tectogene Region. ITC-International Institute for Aerospace Survey and Earth Sciences, The Netherlands, $198 \mathrm{~h}$.

Wiratmo (2013) A Course of Introductory of Climatology and Meteorology in Earth Sciences Olympiad Training. Unpublished.

Zazoeli and Negoro (1989) Atlas Persada dan Dunia. Ghalia Indonesia, Jakarta. 